WARD Roger, Peirce and Religion: Knowledge, Transformation and the Reality of God

Lanham, Lexington Books, 2018, 184 pages

\title{
Claudio Davini
}

\section{(2) OpenEdition}

\section{Journals}

Electronic version

URL: http://journals.openedition.org/ejpap/1773

DOI: 10.4000/ejpap. 1773

ISSN: 2036-4091

Publisher

Associazione Pragma

\section{Electronic reference}

Claudio Davini, « ward Roger, Peirce and Religion: Knowledge, Transformation and the Reality of God», European Journal of Pragmatism and American Philosophy [Online], XI-2 | 2019, Online since 24

December 2019, connection on 24 September 2020. URL : http://journals.openedition.org/ejpap/1773 ; DOI : https://doi.org/10.4000/ejpap. 1773

This text was automatically generated on 24 September 2020 .

\section{(c) (1) $\odot \odot$}

Author retains copyright and grants the European Journal of Pragmatism and American Philosophy right of first publication with the work simultaneously licensed under a Creative Commons AttributionNonCommercial-NoDerivatives 4.0 International License. 


\title{
WARD Roger, Peirce and Religion: Knowledge, Transformation and the Reality of God
}

Lanham, Lexington Books, 2018, 184 pages

\author{
Claudio Davini
}

\section{REFERENCES}

WARD Roger , Peirce and Religion: Knowledge, Transformation and the Reality of God, Lanham, Lexington Books, 2018, 184 pages

1 Widely known among philosophers and scholars as one of the most important logicians in the history of Western philosophy, C. S. Peirce is not equally known as an intellectual whose work was guided by theological views. In other words, compared to his profound contributions in other areas - logic, semiotics and epistemology, to name but a few -, the religious dimension of Peirce's thought has not yet received all the attention it deserves. What explanations can be given of this neglect? Firstly, as pointed out by M. L. Raposa, Peirce wrote very little that can be considered explicitly devoted to this topic. Secondly, Peirce's contributions in several branches of knowledge - not to mention the fact he can be regarded as the most important founding father of pragmatism - may have tended to eclipse what he had to say about religion. In fact, this neglect has proved itself to be unfortunate and infelicitous because what Peirce wrote about logic, semiotic and epistemology is intricately linked to his religious ideas. Roger Ward's new book sheds light on Peirce's religious thinking and examines his religious ideas in relation both to his biography and to his philosophical system.

More precisely, Ward proceeds both systematically through Peirce's work and biographically through his life. This is a quite distinctive and peculiar feature of Ward's book since there are few volumes about Peirce that intersperse philosophical analysis with biographical reflections and that investigate how Peirce's work continuously 
evolved in response to new experiences and shifting circumstances. In short, Ward tells a story about the evolution of Peirce's religious beliefs from his youth to his later years up until his death in 1914 and argues that Peirce's religious perspectives exercised a great influence on the development of his philosophical system. To put it otherwise, the background of Christianity is an essential element to properly understand Peirce's reflections.

The story Ward tells us begins with the description of three early influences on young Peirce's religious personality. First is the figure of his father, Benjamin Peirce Sr. - a remarkable scientist who held the chair of mathematics and astronomy at Harvard College and who is now considered the most brilliant mathematician to have appeared in America before the Civil War -, "whose deeply religious approach to mathematics and science established the grounds of Peirce's religious understanding" (3). Next is Harriet Melusina Fay, who made Peirce leave his family's Unitarianism to join her tradition in the Episcopal Church. The third is Frederic Dan Huntington, Plummer Professor of Morals and Harvard preacher from 1855 to 1859, when Peirce was an undergraduate student.

Benjamin Peirce Sr. was an intensely religious thinker, "often expressing his convictions of a biblical Unitarian faith in evolutionary scientific terms" (3). He also used to think of God as a Creator who reveals his divine character in the physical laws discovered by science and, furthermore, his evolutionary rationalism held that the universe was progressing as an expression of an infinite mind. Indeed, this concept of cosmic evolution would profoundly influence C. S. Peirce's cosmology and would bring about his hesitations toward C.R. Darwin's evolutionary theory, which he always considered to be incapable of accounting for the teleological functioning of the human mind. In the early 1860s, Peirce Jr. married Melusina Fay - her father was a Harvard classmate with Benjamin Peirce and their families were friends - and moved over to Trinitarianism and the Episcopal Church. As Ward puts it, Charles and Zina - as she was called by family and friends - developed a quasi-pragmatist conviction about the proper goal of human life, which "included the commitment to prove the truth of one's beliefs by living them as a means of changing currently held beliefs and practices" (6). Notwithstanding, though he abandoned Benjamin's Unitarianism, C.S. Peirce developed many of his father's other ideas, for example, about the significance of scientific inquiry as a religious vocation and the ideality of nature. In this regard, Ward reminds us that Peirce Jr. credits his father in the Century Dictionary in 1889 with IdealRealism. As previously mentioned, Ward discerns a third influence on C. S. Peirce's thinking, that of Professor Huntington, who entered the Episcopal Church in 1860. Ward's argument is that there are linguistic and conceptual echoes of Huntington's sermons in Peirce's 1863 oration entitled "The Place of Our Age in the History of Civilization."

But the examination of this early lecture is just the beginning of Ward's compelling story. In Chapter 2, Ward convincingly argues that Peirce's Christian commitment is essential to his logic. Actually, Peirce believes that thought is a species of symbol; the interpretant of the symbol is essentially identical with the symbol and also the ground of the comprehension of the symbol is basically equal to it, since it completely determines the symbol itself in all respects. As Peirce says, "[this is the] divine trinity of the object, interpretant, and ground, [and] each fully constitutes the symbol and yet all are essential to it" (CE: I, 503). He also adds that this trinity agrees with the Christian 
Trinity, the interpretant being the Divine word and the ground corresponding to the function of the Holy Spirit. In this regard, "completing the pattern [would mean] the object is Father" (32), but Ward tells us that Peirce hesitates at this point. In short, Ward illustrates how Peirce's relationship to Christianity supplies the background against which his logical thinking unfolds.

In Chapter 3, Ward shows us Peirce's challenges of the utilitarian claim of the primacy of human self-interest with the claim that the social principle is rooted intrinsically in logic and contends that the so-called "conversion to community" is deeply connected to his understanding of the church. In Ward's words, "the centrality of a 'community of inquirers' in [Peirce's] later work is an indication of his persistent commitment to the Christian tradition" (40). Ward also specifies that Peirce's attention to logic and community has origins in his religious convictions - convictions which subtend his philosophical development.

7 In Chapter 4, Ward reminds us of the crisis Peirce suffered in 1876, when he collapsed in a nervous breakdown at the end of the year working in Europe. His father ordered Peirce's wife to retrieve him from Paris and she did so. But when Peirce moved to New York to continue his work with the U.S. Coast and Geodesic Survey, she did not go with him. This separation ended their 15-year marriage and his connection to the Episcopal Church as well. Moreover, Ward affirms that in 1878 essay "The Order of Nature" Peirce rejected one of the most important ideas of his father's religious approach to science, claiming that science is hostile to any religion. In this respect, Ward speculates that this ideological rupture "must have weighed heavily on Charles, especially since it was followed soon after by his father's death" (57). Nevertheless, Peirce would change his mind again; indeed, in 1908 article "A Neglected Argument for the Reality of God," he would show that the disjunction of science from religion is unjustified because, as Ward puts it, "science apart from religion loses its objective force [and] religion without scientific discipline stands on unsure foundations" (129).

8 Taking the discussion a little further, Ward considers that the above-mentioned Peirce's period of crisis - that begins around the time of his separation from Melusina Fay in 1876 and continues into the 1880s, and that is one of the many periods of time in Peirce's adult life that are marked by some sort of crisis - can be defined as "atheistical." To be more accurate, Ward says that Peirce's "Illustrations of the Logic of Science," an early and essential work in the philosophy of science which contains, in addition to "The Order of Nature" and other essays, his two most influential papers, "The Fixation of Belief" and "How to Make Our Ideas Clear," is written "against the dark background of religious absence in Peirce's life at the time leading him to argue for the 'atheistical issue' of science" (xv). Conversely, I believe there are no robust grounds for concluding that Peirce had stopped seeing himself as a Christian in that period and that therefore he had developed atheistic philosophical perspectives, even if he ceased to be an active member of the Episcopalian Church. Firstly, as also pointed out by M. L. Raposa, the views articulated in Peirce's 1878 article "The Order of Nature" are consistent with those that he would defend later in his life; indeed, albeit Peirce writes that "the spirit of science is hostile to any religion" (CP 6.426), we have to keep in mind that his statement is made within a context in which he seems to criticize those priests who do not consider themselves "teachers of religion in general [but teachers] of the particular system of theology advocated by their own party" (CP 6.427), and not to reject religion itself. Secondly, in "The Fixation of Belief," Peirce describes 
the transition from the method of tenacity - that is, a method of inquiry which consists in taking up a private belief and sticking to it - "to a scientific philosophy as seeking a method of resolving doubt into settled opinion" (60). As it is known, the scientific method entails the existence of a community of inquirers, and the centrality of such a notion - a notion which is deeply connected to Peirce's understanding of the Church, as we have already seen - seems to be an indication of his never-ending commitment to Christianity. In other words, I would not think that Peirce's divorce from Zina and his above-mentioned period of crisis could be considered abyss-like experiences which developed him into doubt about the truth of Christianity in such a way as to make him reflect in atheistic terms, and consequently I would not be so sure there is clear break between the 1878 articles and the later ones. I think my view is precisely confirmed by what Ward himself writes in the following of his book, as I will try to show in the next paragraph.

In fact, Ward tells us that Peirce made a Sunday morning visit to St. Thomas Episcopal church in New York in the Spring of 1892 and that he had an experience that compelled him to write to the rector of the church. Peirce confessed the rector he had always had a passionate love for the church and a complete faith that the essence of Christianity was Divine, and Ward argues that "the effect of this return to the church is apparent in the "Monist' essays written after this date" (59); the 1892 article "The Law of Mind," for example, contains the notion of God as a personal creator. More precisely, Ward uses the above-mentioned notion of "return" in a physical and habitual sense, completely rejecting the idea that Peirce could be able to ever entirely separate his thinking from the relation to religion. So, I do not believe we can say that there was a "dark background of religious absence in Peirce's life" (xv) when he published his famous "Illustrations of the Logic of Science."

10 Further in the book, Ward also argues that Peirce's religious ideas are linked to the practical effects that pragmatism promises and that become materialized in willful choices and action. In his own words, "[these ideas] play both a background role in shaping this demand and provide the content for its manifestation in practice" (101). Then, after interestingly and incisively examining Peirce's early logical and semiotic investigations and the development of his pragmatic ideas in the 1870s, Ward goes on discussing the emergence of his "pragmaticism" in the 1890s and the blossoming of his bold and fascinating cosmological conjectures.

11 Finally, Ward takes into account Peirce's last published essay "A Neglected Argument for the Reality of God" and recognizes the confessional character of the argument itself as a product of his own pragmatism, adding that such a character "is relevant for understanding scientific logic as conducing to the truth of religion" (131). He also shows us the importance of both Peirce's philosophy of human instinct and his theory of scientific inquiry for understanding that argument. Moreover, Ward examines Misak's and Anderson's resistance to Peirce's confessional project of reconciling scientific thought to the living character of a Real God, saying that Misak is wrong not to recognize self-controlled growth in the conduct of life as a criterion for testing the consequences of believing in God's reality.

12 Contrary to Ward's thesis, I would argue that Misak is quite right in thinking that Peirce does not show any testable empirical consequence of the belief in God's reality, even if "he boldly asserts that he has shown [such consequences]" (Misak 2013, The American Pragmatists, 45). In fact, the pragmatic maxim - a principle of inquiry which is 
"no doctrine of metaphysics, no attempt to determine any truth of things [but merely] a method of ascertaining the meaning of hard words and of abstract concepts" (CP 5.464) - states that to determine the meaning of a cognitive sign we must "consider what effects, which might conceivably have practical bearings, we conceive the object of our conception to have" (CP 5.402), and Peirce does not clearly show what the effects of the concept of God are. More precisely, Peirce suggests that if "God is real" were true, then we would expect there to be a tendency toward habit-taking and growth, and also that things would be harmonious in the world. As can be seen, it is not at all clear what we would expect if such a hypothesis were true, nor is it clear that we would expect what Peirce says. As Misak puts it, "[Peirce] seems to have been aware of the sogginess of his argument, for each time he begins to talk about 'tracing out a few consequences of the hypothesis', he quickly changes subject" (Misak 2004, Truth and the End of Inquiry: a Peircean Account of Truth, 32). However, I do not think Peirce's lack of success in showing the pragmatist legitimacy of the metaphysical hypothesis "God is real" is indicative of the paucity of pragmatism.

In summary, the author of Peirce and Religion provides us with a persuasive demonstration that Peirce's religious ideas and perspectives about community, conversion, love as agape and Trinity play a crucial role in the construction of his complex philosophical system, a crucial role that has not yet been fully recognized as such. But ignoring Peirce's Christianity and the religious dimension of his philosophical personality would mean the risk of misunderstanding key elements of his reflection. In conclusion, Ward's book offers us a very deep vision of Peirce's pragmatism - a vision that anyone seeking insight into the development of his pragmatic thought should have to confront with.

\section{AUTHORS}

\section{CLAUDIO DAVINI}

University of Pisa

claudiodavini1995[at]gmail.com 